\title{
Analysis of the Privatization Process in Albania and the Impact that Brings the Strengthening of the Banking System
}

\author{
Msc Naser Bilalli ${ }^{1}$ \\ Seeu University, Tetovo, Macedonia \\ Email:n.bilani@seeu.edu.mk
}

Prof Dr Alba Robert Dumi²

Dean of Graduated School, Management Department" Economy Faculty University of Vlore, Albania

Email: alba.besi12@gmail.com

\author{
Doi:10.5901/mjss.2016.v7n2s1p365
}

\section{Abstract}

Financial activity in Albania as well as in other countries of Eastern Europe during the past few years has seen a significant developments and important. One of the main features observed is that financial activity in Albania is dominated by banking activity, while non-banking activity remains extremely limited. The investment funds in Albania According to specification in the Albanian legislation "Investment Fund" could be any private entity, that are accumulating financial resources of natural or legal persons (Bonus letters, Vouchers, cash); · Broadcasts only its shares in exchange for them; · Invests, reinvests, owns or trades bonus letters. An investment fund established and organized as a joint stock company in accordance with legislation. It is a society with a large number of owners and that only at the beginning is engaged in collecting vouchers and use them to buy shares of companies that will be privatized.

Keywords: Financial activity, investments, bonus, supervision.

\section{Introduction}

At the end of 2007, total assets of the banking system constituted about $96.8 \%$ of total assets of the entire financial system, while those of non-bank system only 3.2\%. Therefore, it is evident the need to reform the nonbank financial system and to enable supervision by the best practices it. The goal served to the establishment of the Financial Supervision Agency in 2006. The development of non-bank financial intermediaries and capital markets would provide alternative ways of financing, and will have a positive impact on increasing the efficiency and competitiveness of the financial system.

Another important trend is that the degree of banking intermediation in Albania has increased considerably in recent years, but it is low compared with that of the euro area. Total assets of the banking system to GDP in Albania was respectively $76 \%, 69 \%$ and $60 \%$ at the end of 2007, 2006 and 2005 respectively.

This indicator for Albania is close to the average for the countries of Eastern Europe, but it remains far from the average for the euro area countries where the value reaches $240 \%$. The growth of banking intermediation is also seen in increasing the diversity of financial products in large geographical territorial coverage and rapid credit growth.

\subsection{Loan indicators and GDP growth}

Loan outstanding in Albania has shown higher annual growth rate: 48\%, 55\% and 82\% during the years 2007, 2006 and 2005 respectively. Thus, Albania was identified as one of the countries with the highest growth of credit during these three years. However, outstanding credit to GDP in Albania for 2007 was $30 \%$ and for 2006 was $22 \%$, which was low compared with that of the eurozone.The study of "Banking in Eastern Europe" by the research team of Deutsche Bank, among others, estimates which should be an equilibrium level of private sector credit to GDP for some countries in the region, in caseit would be achieved the convergence with the Eurozone.

According to this study, this level for Albania should be around two times higher than the current level. In this regard, rapid credit growth, on the one hand, explained as a necessary process of convergence that helps economic growth supported by domestic demand and the fact that is calculated on a very low initial phase.On the other hand, it is 
interpreted as a dangerous phenomenon as price stability by affecting aggregate demand, both for financial stability through the display of volatile prices for various assets.

\subsection{The purpose of the study}

The purpose of the study is to check the system evaluation from 2004-2010 until today. The rapid growth of credit in many countries has been accompanied by a significant increase in prices of various assets, such as the price of real estate, which later exploded and adversely affectied the value of collateral and the quality of loans issued against them. The evaluation of the employees was made of two phases:

- The first evaluation ( Primary data \& Secondary data)

- The last evaluation. ( ESPS method \& Statistical method)

The most recent case of the consequences of this phenomenon is the market crisis "subprime" in the United States, which has not yet exhausted its negative consequences and contamination for other countries. This crisis appearing as a liquidity crisis, with direct impacts on capital markets associated with the the food crisis, and the rapid increase in oil prices has raised many questions about the development prospects of the world economy.

The Bank of Albania assesses that the difficult situation that international financial markets are going through represents a new element of risk for the Albanian financial system. But, as long as it does not turn into a global financial crisis with global repercussions on the real economy and particularly in Europe, it will be relatively insensitive to the domestic market.

\subsection{International financial markets and internal funds}

In support of this conclusion is relatively low the development of the domestic financial market and the lack of sophisticated products such as derivatives instruments, which are absent in the portfolios of our banks. This conclusion also influencing relatively low needs to represent the Albanian financial institutions to finance the international market, since it still has room for internal funding sources.

Consequently, the ratio of nonperforming loans to total outstanding loans (gross) displayed lower levels but with an upward trend, being $3.4 \%, 3.1 \%$ and $2.3 \%$ for the years 2007,2006 and 2005 respectively. The latest measures in this respect are the entry into force of the new law "On banks in the Republic of Albania" in June 2007 and the adoption of new regulations and the amendment of existing ones, which put the emphasis on a more effective supervision, in accordance with European Union directives and principles of the Basel Committee.

Also, the Bank of Albania conducted the operation of the Credit Registry in January 2008. Offering a very important instrument for deepening the analysis and reducing credit risk by banks. If we talk about the structure of the loan, it has undergone changes in recent years both in terms of economic sectors, maturity or currency.It is worth mentioning that despite the changes, some features are dominant for a long time in the system, the Albanian banking. Despite positive developments in terms of growth in lending to individuals, banks continue to have businesses as the most preferred segment of them, where the loan balance for the latter accounts about $63 \%$ of system loans at the end of 2007.

Thus, the most credited sectors as trade, processing industry and construction, while lending for one of the most important sectors, such as agriculture, remains limited. Lending in foreign currency is another characteristic of the Southeast European countries and Albania.Despite the weight of credit in ALL(albanian lek) has increased over recent years, it remains low. In terms of maturity, the banking system is characterized by a shift towards medium-term credit and especially the long-term, this is also a result of increased demand for these types of loans in the context of the diversity of products that banks already offer.

\section{Literature Review And Hypotheses}

The demand for purchase and construction of houses (especially the metropolis where the population concentration is high) has been on the increase, coupled with an increase in the demand for loans, for real estate. This product is already considered as one of the types of loans, with interest to banks, and for customers.

The weight of this loan has increased and in the first quarter of 2008 constituted about 24 percent of the loan portfolio of the Albanian banking system. However, it is worth noting that while the Central Eastern European countries are reaching double-digit levels report for real estate loans to GDP while countries in the region, including Albania, are at much lower levels.

Hypothesis: 1. Another feature highlighted in the banking system and those of most countries of Eastern Europe 
is the high cost of intermediation, which has been on the increase, although rate growth has slowed.

Hypothesis: 2. This high margin refers to increasing the investment bank in assets with higher risk and change in the structure of deposits in favor of those in foreign currency with low interest rates.

Hypothesis: 3. According to an IMF study assumed that these high intermediation costs are impeding economic development of the region and are showing a lack of efficiency.

The change of business environment through institutional reforms and the promotion of competition among banks, non-banking sector development, would be the appropriate steps to increase efficiency and reduce costs of financial intermediation

\subsection{Research Goal}

It constitutes positive tendency to increase the role and interest of large financial groups to enter into Albanian banking market and in the Eastern Europe. Currently in the Albanian banking market are operating the actorssuch as Austrian (Raiffeisen Bank), Italian (San Paolo IMI), French (Societe Generale), Turks, Greeks, Bulgarians, Arabs, etc..

Foreign investments are assessed as very important for developing countries, since they positively influence on the macroeconomic, technological and institutional host countries. Wide experience of recent decades shows that FDI (Foreign Direct Investment) financial, improve the health of the domestic financial system through better management of portfolio risk and a more efficient allocation of credit funds.Also, the technological innovations of financial FDI increases the level of competition and efficiency in the banking system, increasing the number of products and services.Despite these positive effects, the presence of foreign banks in the country instigates improvements in the institutional framework and promoting the application of international accounting standards, reporting and checking up which helps not only in decision-making of commercial banks, but also the Central Bank.

The long presence of foreign banks in the Albanian banking system has led to the establishment of a stable banking system.Despite the financial collapse of 1997 or the panic crisis in 2002, in any case, the system's performance has not been a source of crisis or instability. However, the economic benefits from the presence of foreign banks have not yet reached the proper degree. They are still far from what we would like in terms of increasing the quality of information provided to the general public, as well as the Central Bank, reducing the cost of mediation, further improving risk management and unification of accounting systems and financial reporting.

A very important role is played by international financial institutions such as the IMF, World Bank, European Bank for Reconstruction and Development, European Investment Bank etc., in terms of assistance and promotion of the financial system, both in mediation terms of financing and investment.Moreover they are in support of economic growth and sustainability of the current account.

\subsection{Safety and risks of the banking system.}

The capital adequacy indicator for the banking system was $17.1 \%, 18.1 \%$ and $18.6 \%$ for the years 2007,2006 and 2005 respectively, being above the $12 \%$ required by the regulatory framework. Despite the existence of a long-term trend of decline of this indicator, the rate of decline in the last three years is less than in previous years.

Also, the banking system in Albania enjoys satisfactory profitability indicators. For the years 2007, 2006 and 2005, respectively, return on average assets was $1.57 \%$ has been, $1: 36 \%$ and $1.4 \%$, while return on equity was $20.74 \%$, $20: 17 \%$ and $22: 24 \%$. On the other hand, there are risks that need to be treated with due diligence. Rapid credit growth need to be monitored carefully in terms of its quality, and this is one of the current focuses of the Bank of Albania.

Also, another risk is that of the exchange rate. Loan outstanding in foreign currency is $72.5 \%$, while the income of the private sector and individuals are mainly in ALL(albanian lek). Consequently, a possible devaluation of the ALL(albanian lek), driven by the need to reduce the trade deficit, will negatively affect the solvency of the borrowers in foreign currency and further the quality of these loans.

Finally, the unfavorable dynamics of the prices of energy, the raw materials and the food products, increases the inflationary pressures and might affect the financial system as a result of tightening monetary and of internal or external financial conditions.

As a result of reforms the Albanian banking system, the most dynamic part of the financial system has made significant progress in recent years.

This progress is the result of a clear vision and the seriousness by which the Albanian authorities as been treated in reforming the banking system,effective cooperation that these authorities have had with international financial institutions like the IMF and WB, for draftingfurther medium-term strategies for the development of this sector as a vital 
sector of the market economy, as well as the numerous challenges which it is facing over the years.

\subsection{Competition in the banking system}

Defined as "the rivalry between providers of goods and services in a market" the competitiveness is a very important aspect of the banking system because it affects the efficiency and quality of products offered.

We can also say that the level of competition also affects other sectors of the economy. Empirical evidence shows that a high level of competition in the banking sector, are leading to a rapid growth of other sectors of the economy (Claessens and Laeven, 2005).Also, Deidda and Fatouh (2002) argue that the concentration in the banking sector negatively affects economic growth in countries with low incomes, but not in countries with high incomes.

This means that the developing countries need a banking system with high competition in order to enhance the rate of economic growth. On the other hand is thought that there is anopposite connection between competition and stability in the banking sector.The banking market is a very important sector, which brings high costs in the event of bankruptcy.Because governments are likely to save the banks from bankruptcy the latter ones may be inclined towards risk consciousness.

Taken into account these factors, Vives (2001) argues that a high level of competition can lead to obtaining a higher risk from banks, which increases the possibility of bankruptcy. This mutual respect is even more apparent in developing countries.Meanwhile the developed countries with a high level of competition can keep under control of the banking system for countries in development and that is a hard thing.

Therefore the developing countries is preferred to have a competitive moderatedbanking system.Let's see the performance of Herfindahl index, which measures the degree of market concentration. The market has a moderate Competition level if

- The market is full competition if the index is $\mathrm{HHI}<1000$

- The market has a moderate Competition level if $1000<\mathrm{HH}<1800$

- The market is full concentrate if $\mathrm{HHI}>1800$

\begin{tabular}{|c|c|c|c|c|c|c|c|c|}
\hline HHI & $\mathbf{1 9 9 9}$ & $\mathbf{2 0 0 0}$ & $\mathbf{2 0 0 1}$ & $\mathbf{2 0 0 2}$ & $\mathbf{2 0 0 3}$ & $\mathbf{2 0 0 4}$ & $\mathbf{2 0 0 5}$ & $\mathbf{2 0 0 6}$ \\
\hline Active & 4,795 & 4,382 & 3,757 & 3,226 & 3,016 & 2,736 & 2,110 & 1,949 \\
\hline Credit & 3,316 & 2,727 & 2,011 & 1,729 & 1,459 & 1,150 & 1,035 & 1,035 \\
\hline Deposits & 5,719 & 4,966 & 4,282 & 3,676 & 3,487 & 3,107 & 2,391 & 2,105 \\
\hline
\end{tabular}

Source: Bank of Albania, The market HHI

From the above data we can say that the market and the market deposits of assets are considered highly concentrated.Deposit market is more concentrated market, where the three largest banks hold the bulk of the deposit

A phenomenon discovered in the calculations is that banks are dominant market share in deposits and assets are not dominant credit market.This means that the concentration of assets and deposits market is not broadcast in the credit market.

This may have been due to two factors:

- Disengagement deposits in lending by some banks

- Use of high levels of capital, in the absence of sufficient deposits from other banks

Despite the concentration in the credit market is at satisfactory levels,the concentration in deposit market remains disturbing phenomenon because deposits are the most important factor that dictates the level of lending banks.

\subsection{What does index C4 say?}

From the data financial indicators of commercial banks can be calculated the index of a concentration of assets, deposits and credit and we can make a comparative analysis with HHI Idex.

From Managerial Economics bookwe know:

$C 4=\frac{S 1+S 2+S 3+S 4}{S T}$

From corresponding data the four banks dominating the market can raise the degree of concentration of assets.

$C 4=\frac{221045.24+81342.16+80303.34+49945.33}{624279.28}=0.693$ 

deposits.

Taking respective total deposits of four banks dominating the market can get the degree of concentration of

$$
C 4=\frac{201883.32+74329.54+42179.57+54993.98}{520281.86}=0.71766
$$

Në të njëjtën mënyrë llogarisim edhe shkallën e përqëndrimit në tregun e kredisë.

$C 4=\frac{37230.51+21769.20+26287.05+25156.37}{196864.51}=0.5610$

The Indicator C4takes half value segmented(0,1].As much closer to number 1 is $\mathrm{C} 4$ as much higher will be the concentration degree of market, so the least competitiveness the market has.

According to data obtained from the above monitoring report 2006 the same conclusion is reached that we had in the case of the $\mathrm{HHI}$ index. As we see market remains the deposit problem which has pointer highest $\mathrm{C} 4$ which means that it is less competitive.The market with competion isthe credit market that has this indicator compared with close to zero in two other markets.

However, the monitoring report for 2007 noted $\mathrm{HHI}$ for 2007 has been reduced assets and deposits and the loan has not changed.Values close to zero indicate a high competition and state their values close to one of the high market concentration.

The banking system in Albania has significantly and importantly increased.A very important aspect of the development of the banking sector and is the competitiveness. It is rather a micro point of view but it is very important as regards of the development and the progress of this sector. It is observed in the banking sector that the depositsmarket is more concentrated market, followed by the assets market and the credit market.From the calculation of the indicators of concentration as $\mathrm{HHI}$ or 4 is noted that this year as well as last years market assets and deposits have higher degree of the concentration than the credit market, however for the first quarter of 2008 is observed a reduction in the level of the market's concentration in assets and deposits while loan market shows an increasing degree of concentration.

We know that the increased competition in the banking sector affects not only the development of this sector, but also affects the growth of other sectors. However we can not say an absolute definition on the optimal level of competition for a high level of competition which can lead to obtaining a higher risk from banks, which increases the bankruptcy possibilities. This mutual respect is even more evident in developing countries such as Albania.While developed countries with a high level of competition can keep control of the banking system for countries in development which is a hard thing. Therefore, for developing countries like Albania is preferably a competitive moderatedbanking system.

It has been noted from Research studiesthat the level of lending in Albanian is still at low levels and to accelerate the economic growth, the lending activity should be increased but the rapid growth of credit, on the one hand, is explained as a necessary process of convergence that helps the economic growth supported by domestic demand and the fact that is calculated on a very low initial phase.

On the other hand,it is interpreted as a dangerous phenomenon as price stability by affecting aggregate demand, for financial stability through the display of volatile prices for various assets.

\section{Conclusions and Recommendation}

The rapid growth of credit in many countries may be associated with a significant increase in prices of various assets, such as the price of real estate, which later exploded and adversely has affecting the value of collateral and credit quality issued against them.

Rapid credit growth needs to be monitored carefully in terms of its quality, and this is one of the current focuses of the Bank of Albania. Also, another risk is that of exchange rate.Consequently, a possible devaluation of ALL(albanian lek) is driven by the need to reduce the trade deficit, which will negatively affect the solvency of the borrowers in foreign currency and further more the quality of these loans.

Another factor that I think increases the risk of credit is the fact that wages are in ALL(albanian lek) and the bulk of the loan portfolio is in euros, reduction of interest rates on loans in Lek(albanian lek) can lead to the improvementof the quality of the loan portfolio .

\section{References}

J. B. Barney, 1994, Commentary: A hierarchy of corporate resources, in P. Shrivastava, A. Huff, and J. Dutton (eds.), Advances in Strategic Management 10A, (Greenwich, Conn.: JAI Press), 119.

J. B. Barney, 1991, Firm resources and sustained competitive advantage, Jonmal ofManagement 17: 99-120.

D. J. Collis and C. A. Montgomery, 1995, competing on re- sources: Strategy in the 1990s, Harvard Business Reviezo 73, no. 4: 118- 
128.

R. M. Grant, 1995, Contemporary Strategy Analysis, 2nd ed. (Cambridge, Mass.: Black well Business), 138-140.

R. A. D'Aveni, 1995, Coping with hyper competition: Uti- lazing the new 7S's frame work, Academy ofManagement Ex- ecutive IX, no. 3: 54; D. Schendel, 1994, Introduction to the Summer 1994 special issue-Strategy: Search for new paradigms, Strategic Mangement Joumal (Special Summer Issue) 15: 3.

P. Shrivastava, 1995, Egocentric management for a risk so- city, Academy ofManagement Review 20: 119.

R. P. Rumelt, D. E. Schendel, and D. J. Teece (eds.), 1994, Fundamental Issues in Strategy (Boston: Harvard Business School Press), 527-530; A. D. Meyer, 1991, What is strategy's distinctive competence? Joumal of Management 17: 821-883.

Schendel, Introduction to the summer 1994 special issue, 1-3. 